\title{
Are Temporary Foreign Workers Filling only Labor Shortages? The Case of Canada
}

\author{
Dominique M. Gross \\ School of Public Policy, Simon Fraser University \\ Harbour Centre, 515 West Hastings St., Vancouver, V6B 5K3, Canada \\ E-mail: dgross@sfu.ca
}

Received: Dec. 28, 2016 Accepted: Jan. 25, 2017 Published: Feb. 15, 2017

doi:10.5296/csbm.v4i1.10717～URL: http://dx.doi.org/10.5296/csbm.v4i1.10717

\begin{abstract}
A temporary foreign worker (TFW) program is meant to fill short-term labor shortages and, constraints are imposed on employers for resident workers not to be affected in getting jobs. Often, employers consider that such a program imposes time-consuming administrative barriers and they pressure the government to obtain easier and faster access to TFWs. The Canadian policy was modified in two Western provinces from a required high time-consuming labor market test for all occupations to prove labor shortages to an immediate hiring of TFWs for occupations in a given list. Using DDD, it is tested whether priority to local workers was ensured under the new program. The analysis shows that much faster access to TFWs accelerated rises in unemployment in some high- and low-skill occupations and, impacts were quite different across the two provinces and industries. Thus, some domestic workers have been negatively affected. The main cause was a lack of clear information about local occupational labor shortages and political supports to employers for cheaper labor.
\end{abstract}

Keywords: Temporary Foreign Workers, Unemployment, Business Pressures, Canadian Policy 


\section{Introduction}

Temporary foreign worker programs address labor shortages to ensure steady economic growth and avoid sharp wage increases in the short run. In today's world many countries implement such a policy to ensure labor market flexibility. In Canada, the temporary foreign worker (TFW) program was introduced in 1973 for a few occupations and, by 2002 it was covering all occupations. From then and until 2014, rules have been repeatedly relaxed mostly under pressures from businesses which found access to TFWs high time consuming. A growing question has been whether this program was really filling its economic goal, which is giving employers access to needed labor without negatively affecting local workers. In this paper, a pilot project which eliminated the constrained time process to employers for specific occupations in two provinces is used as a natural experiment to evaluate whether domestic workers have been affected to get jobs.

A TFW program potentially provides access to a world supply of suitable and potentially cheaper workers. To ensure that employers give hiring priority to domestic workers, there are basically two systems which impose constraints: A labor market test (LMT) and, a specific occupation list. The LMT must prove that employers cannot find suitable workers domestically before the government agency authorizes TFW hiring. This process generates challenges as Ruhs (2006, p. 19), states "Such tests have proved notoriously difficult to implement in practice not least because employers have shown considerable ingenuity in ensuring that no local workers are found to fill their vacancies (...). Clearly, without the right incentives and enforcement, any labor market test simply becomes a bureaucratic obstacle that serves neither employers nor local workers.” As a consequence, there are often strong businesses' motivations to pressure the government to ease the LMT process. The alternative system is the availability of a list of occupations with deep labor shortages set-up and regularly revised by the government. A required feature for both systems is clear information about the states of local labor markets at occupation levels. In case of perfect information, the occupation list system is faster and cheaper for firms and, it can improve economic growth at no cost for domestic workers.

Historically, in Canada, the TFW program has used the LMT system with employers having to provide a Labour Market Opinion (LMO). (Note 1) They must state with some proves that they did not find suitable workers domestically and confirm they will offer to foreign workers at least the minimum regulated wage as well as employment conditions applicable to local workers. Then, a federal agency decides to approve or reject their demand for TFWs. Since 2002, increasing business pressures to accelerate processing time led the government to weaken LMOs' administrative constraints (House of Commons of Canada, 2009, Chapter 3). In 2006, a survey of about 12000 independent businesses showed that $60 \%$ mentioned that the top problem in hiring TFWs was delays in processing applications (Bourgeois et al., 2006). Hence, in 2007, the government implemented the Expedited-Labour Market Opinion (E-LMO) pilot project in two Western provinces (Alberta and British Columbia) with relatively low unemployment. The government provided a list of occupations for which employers were guaranteed that LMO applications would be processed within a few days instead of a few months. It was terminated in 2010. The government's reasons for weakening 
repeatedly administrative obstacles and for implementing the E-LMO pilot project, were on-going labor shortages. Yet, there is evidence that the political discourse was not representing states of labor markets. So, the E-LMO pilot project is used as a natural experiment to identify whether local workers were given priority in hiring and thus, not affected negatively.

While there is some empirical literature about the impact of permanent immigrants on the labor market in Canada (for examples, Dungan et al., 2012; Tu, 2010; Islam, 2007; Marr \& Siklos, 2005) there are very few economic studies about the impact of TFWs. At the national level, Gross \& Schmitt (2012) show empirically that the extension of the program to low-skill workers in 2002 contributed to increased persistence in regional unemployment disparities for the five following years. One potential reason is that internal mobility for resident workers was not eased and Beine \& Coulombe (2014) show that provincial inflows of TFWs substantially decreased interprovincial mobility.

In this paper, I show that the E-LMO pilot project, implemented in British Columbia and Alberta from 2007 to 2010, accelerated residents' unemployment rises for some occupation groups. In Alberta, the impact has been relatively small and only for low-skill workers; still more than 3000 people, in a group with the unemployment rate above 10\% have been affected during the whole implementation period. In British Columbia, there has been a total impact of more than 18000 high- and low-skill workers from a labor force of around 340000 people. Overall, much of the impact was on groups without obvious labor shortages. It is clear that weak labor market information in Canada allowed pressures from employers, and support by the government, to access TFWs independently of domestic labor shortages.

The paper is organized with Section 2 overviewing briefly the Canadian TFW program and describing the E-LMO pilot project. Section 3 provides justifications for its implementation. Then, Section 4 shows the policy change as a natural experiment for the analysis and Sections 5 and 6 justify and evaluate the impact of the pilot project on local unemployment rate changes. Section 7 concludes.

\section{The Canadian TFW Program}

\subsection{General TFW Program}

The Canadian TFW program was established in 1973. It was limited to seasonal agricultural workers, live-in-caregivers and, some types of high-skill workers. (Note 2) Over time various streams were developed and, in 2002, the program was extended to all low-skill occupations. For many jobs, employers must provide an LMO to get the authorization of hiring TFWs. Before the re-introduction of constraints, on December 31, 2013, there were 340788 TFWs in Canada and, for 104125 (30.6\%) LMOs had been required (CIC, 2015). (Note 3) In terms of occupations, four streams of TFWs require LMOs with somewhat different regulations: Seasonal agricultural workers, live-in-caregivers, high-skill and, low-skill workers. This paper focuses on the high- and low-skill workers because there are similar administrative conditions and almost all occupations are covered. The LMO is approved by Employment and Social Development Canada (ESDC, formerly called Human Resource and Skill 
Development Canada, HRSDC) from the Federal Government. In addition, the Ministry of Citizenship and Immigration Canada which considers health and security factors provides visas and, ultimately, border officers provide final entry authorizations.

An LMO application requires employers to confirm that the job offer is genuine and, that they have made reasonable efforts to hire or train a Canadian for the job. TFWs must fill labor shortages, create new job opportunities or help retain Canadians on jobs. In addition, TFW hiring cannot affect labor disputes and, working conditions must be comparable to Canadians' ones in similar occupations. The whole LMO process used to take around 4 to 5 months with an administration fee of \$100 until April 2013 when it rose to \$275. In June 2014, it further increased to $\$ 1000$ (ESDC, 2014).

In July 2002, the TFW program was extended to low-skill workers through the Pilot project for occupations requiring lower levels of formal training and some additional conditions were imposed for those workers. Employers had to pay all agency recruitment costs and return airfares. They had to register TFWs under provincial workers' compensation regime, prove they had medical insurance coverage for the duration of the job contract and, support them to find suitable accommodation. In February 2007 the length of work permit for low-skill workers increased from one to two years after which they had to return home for four months. In April 2011 the total length of renewed contracts increased to four years. A return to Canada could occur only after a four-year stay at home (CIC, 2011).

The LMT program also imposes rules for TFWs' wages and future statuses. Until April 2012, employers had to pay at least the regional median wage of the occupation (HRSDC, 2013b). Then, a lower cost was allowed; they could offer a wage up to 15 percent lower than the median wage for high-skill workers and, up to 5 percent lower for low-skill workers as long as it was above the minimum wage. In April 2013, the government eliminated these flexibilities (HRSDC, 2013e). High-skill workers can apply for permanent residency while low-skill workers only have the possibility through some provincial authorizations.

\subsection{The E-LMO Pilot Project}

In September 2007, the Expedited Labour Market Opinion (E-LMO) Pilot Projectwas introduced in two Western provinces, British Columbia (BC) and Alberta (AB). (Note 4) HRSDC first determined employers' eligibility to the project; then, LMO approvals were guaranteed in five days instead of up to five months (HRSDC, 2008). Compliances to the rules could be checked later. To be eligible, employers had to confirm in writing that the occupations they were applying for were consistent with their main business activities; that they had been in operation for a minimum of 12 consecutive months with at least one employed worker; and that they would respond to a call from a government officer to confirm that all provided information was correct (CNC, 2008). Initially, twelve occupations were eligible through E-LMOs. In January 2008, it rose to 33 covering all skill levels. The eligible occupations were taken from lists for which the required job advertising had been decreased from two to three weeks to one week (CNC, 2007a). The pilot project was terminated in April 2010. (Note 5) 


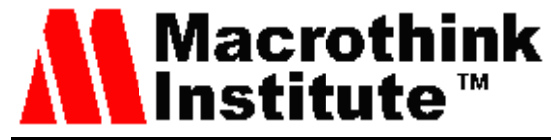

Figure 1 shows total TFW hiring confirmations through LMOs and only E-LMOs from 2005 to 2012. In 2007, there has been a sharp rise in total LMOs in AB and BC (+82.4\%) compared to the rest of Canada (+19.2\%). By 2008, the confirmations of the two provinces were more than twice those of the rest of Canada (94 125 vs 46 755) with $58.5 \%$ of the rise coming from E-LMOs. Even though there was a sharp decline in 2009, LMO confirmations in AB and BC remained larger with $18 \%$ coming from E-LMOs. Out of the 33 covered occupations, 19 were high skilled and 14, low skilled. (Note 6) The share of confirmed low-skill positions increased drastically in $\mathrm{AB}$ and $\mathrm{BC}$, during the pilot project program. It rose from $25.4 \%$ of total LMOs in 2006 to $60.2 \%$ in 2008 and returned to $46.7 \%$ in 2010 (HRSDC, 2013d). In the rest of the country, the share rose from $14.1 \%$ to $23.3 \%$ and then remained at $27.5 \%$. Skill distributions for E-LMOs are not available but the evolutions clearly show that easiest access to TFWs through the pilot project increased substantially hiring of low-skill TFWs.

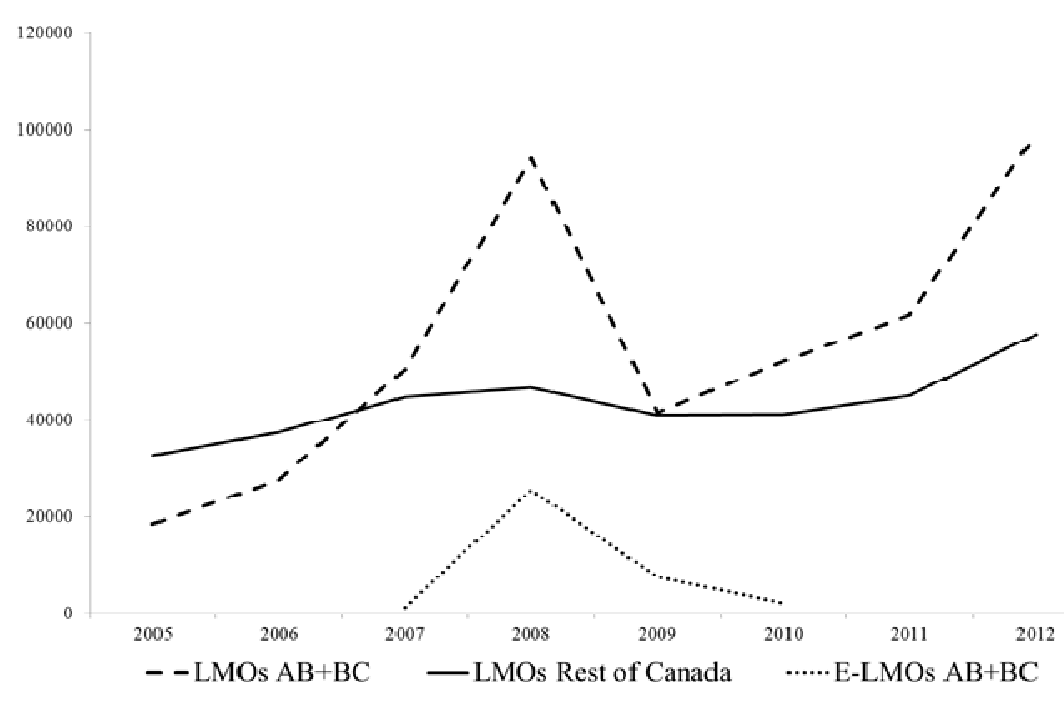

Source: HRSDC (2013d) Tables 3, 7, 9.

Figure 1. TFW positions confirmed through LMOs

In short, the E-LMO pilot project generated a drastic reduction in administrative obstacles for TFW hiring in two provinces during about two and a half years. Since the pilot project was in a given region, for specific occupations and during a fixed period of time, it can be considered as a natural experiment for treatment groups. Statistical conditions for the validity of the analysis are determined in Section 4.

\section{Justification for the Pilot Project}

Economically clear labor shortages must be motivations for an accelerated administrative process in the E-LMO pilot project. Based on available statistics for the pre-experiment period, from 2002 to 2006, AB had the lowest provincial unemployment rate in the country and it kept declining (5.3\% to 3.4\%; Statistics Canada, 2013a, Table 2820010). BC, in 2002, exhibited a rate above the Canadian average (8.5\% versus $7.7 \%)$ but it experienced the 
sharpest drop in the country during the following years and reached $4.8 \%$ in 2006 . By then, all other provinces were between $4.3 \%$ and, $14.7 \%$. The natural rate in Canada having been estimated at $6 \%$ to $7 \%$ (Fortin, 2000) these rates supported strong global economic growth in the two provinces; but, labor shortages had to be considered in specific occupation groups.

In Table 1 there are average unemployment rates for groups covering E-LMO listed occupations (i.e., treatment groups) with provincial rankings before the experiment period. While in $\mathrm{AB}$ no group ranked below third, in BC they were between first and sixth. BC by far did not exhibit the lowest unemployment rates even for high-skill workers. Generally, lower rates were in the Prairies and the Central region (Saskatchewan, Manitoba and Ontario). For two low-skill groups, Construction Labourers (H8) and Manufacturing Processing Labourers (J3), unemployment rates were above 10\% even though they ranked high. Overall, only 12 groups out of 21 exhibited the lowest unemployment rates in $\mathrm{AB}$ and $\mathrm{BC}$; thus, shortages of labor at disaggregated levels were not obvious.

Table 1. Unemployment rates of treatment groups (Average 2002-2006)

\begin{tabular}{|c|c|c|}
\hline \multirow{2}{*}{ Treatment groups } & \multicolumn{2}{|c|}{ \% Unemployment (provincial ranking) } \\
\hline & $\mathbf{A B}$ & BC \\
\hline \multicolumn{3}{|l|}{ High skills } \\
\hline Natural and applied sciences and related occupations (C) & $2.6(1)$ & $4.3(6)$ \\
\hline $\begin{array}{l}\text { Professional occupations in health, nurse supervisors and } \\
\text { registered nurses (D0-D1) }\end{array}$ & n.a. & n.a. \\
\hline Technical, assisting and related occupations in health (D2-D3) & n.a & $2.6(3)$ \\
\hline Occupations in art, culture, recreation and sport (F) & $4.2(1)$ & $5.3(2)$ \\
\hline Construction trades (H1) & $5.7(1)$ & $7.4(2)$ \\
\hline Other trades occupations (H2-H5) & $4.0(3)$ & $5.0(5)$ \\
\hline \multicolumn{3}{|l|}{ Low skills } \\
\hline $\begin{array}{l}\text { Retail salespersons, sales clerks, cashiers, including retail trade } \\
\text { supervisors(G011, G2-G3) }\end{array}$ & $4.5(2)$ & $5.1(4)$ \\
\hline $\begin{array}{l}\text { Trades helpers, construction and transport labourers and related } \\
\text { occupations (H8) }\end{array}$ & $10.4(1)$ & $11.2(2)$ \\
\hline Labourers in processing, manufacturing, utilities (J3) & $10.8^{\mathrm{a} /}(2)$ & $11.1(4)$ \\
\hline \multicolumn{3}{|l|}{ Mixed skills } \\
\hline $\begin{array}{l}\text { Chefs and cooks, and occupations in food and beverage service, } \\
\text { including supervisors (G012, G4-G5) }\end{array}$ & $5.4(1)$ & $6.7(4)$ \\
\hline $\begin{array}{l}\text { Sales and service occupations not elsewhere classified, including } \\
\text { occupations in travel and accommodation, attendants in recreation } \\
\text { and sport as well as supervisors (G013-G016, G7-G9) }\end{array}$ & $5.7(2)$ & $6.2(4)$ \\
\hline Transport and equipment operators (H6-H7) & $5.3(3)$ & $4.7(1)$ \\
\hline
\end{tabular}

Note. Ranking is defined from the lowest to the highest unemployment rates across 10 provinces. ${ }^{\text {a/ }} 2002$ percentage.

Source: Statistics Canada (2013a), Table 2820010. 


\section{MInstitute Macrink $^{\text {Mnth }}$}

Figure 2 shows total unemployment rates for E-LMO listed and non-listed occupation groups in the experiment region. The surprising feature is that during the preceding decade of the pilot project implementation (1998 to 2006), listed occupation groups had overall unemployment rates systematically above the ones of non-listed occupation groups in $\mathrm{AB}$ and BC. So, based on available statistics, there was no systematic best labor market performance for listed occupation groups before the pilot project implementation even if the provincial unemployment rates were low.

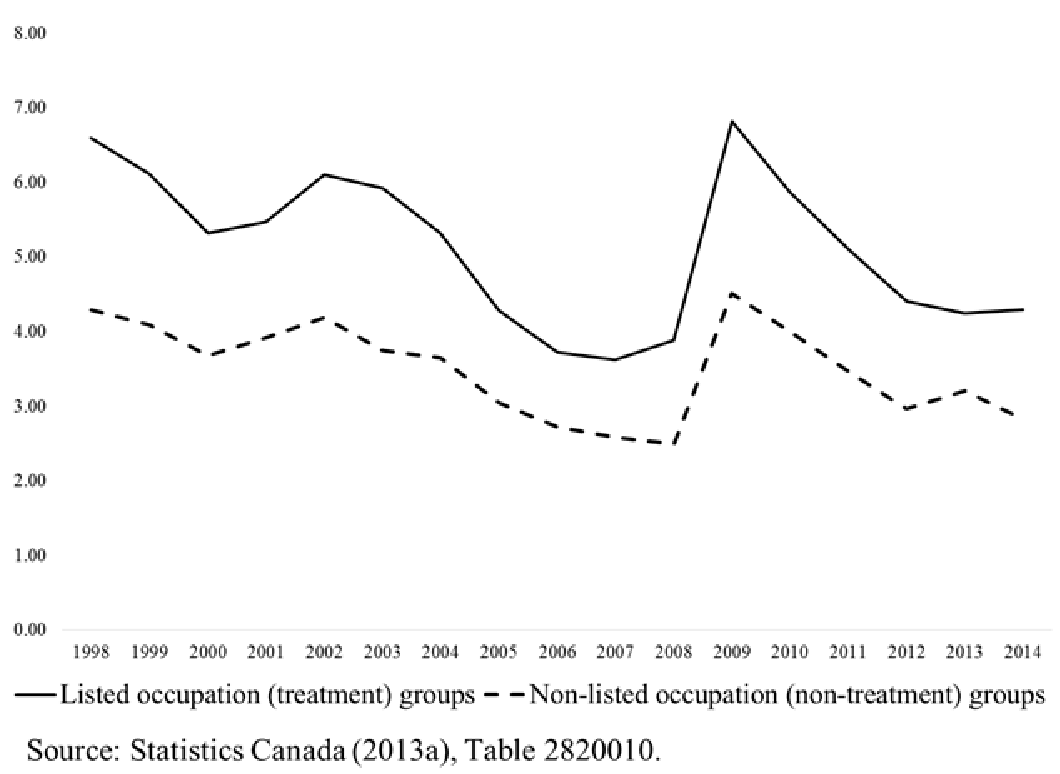

Figure 2. Unemployment rates for occupation groups in the experiment region (AB+BC)

The lack of clear evidence for deep labor shortages to implement the E-LMO pilot project is confirmed by some literature. Rheault (2013) shows empirically, that, between 1996 and 2011, corporate lobbying was an important factor influencing the level of TFWs admitted to Canada and, only $38 \%$ of variance in foreign workers is explained by unemployment (Table 7 , p. 717). In addition, even though politicians were affirming it was done to address growing shortages of labor, the E-LMO pilot project resulted from satisfying some employers' pressures for cheaper access to low-skill workers (Foster, 2012; Fudge \& MacPhail, 2009). Barnetson \& Foster (2014) study the validity of statements made by government members in Alberta about the needs for TFWs. Through a qualitative analysis, it is shown that Alberta government's goal was to convince that there was no impact of TFWs on the labor market. The TFW program was also strongly supported during the 2008-economic crisis. When unemployment started to rise, the justification became that TFWs were addressing long-term issues. This is a surprising argument since TFWs must fill short-term labor shortages (Castles, 2006; Dustmann et al., 1996). Barnetson \& Foster show that between 2000 and 2011, the statements were justifying policy to make labor cheaper and not filling labor shortages. So, discourses were independent of the state of the economy and this requires an analysis to 


\section{Macrothink}

Case Studies in Business and Management

ISSN 2333-3324

2017, Vol. 4, No. 1

identify whether there has been an impact on resident workers' accesses to jobs.

\section{Natural Experiment Characteristics}

For a natural experiment analysis there must be consistency between the treatment groups (on listed occupations) and the control groups (on non-listed occupations) and, between the experiment region $(\mathrm{AB}+\mathrm{BC})$ and the non-experiment region (8 provinces).

Figure 3 shows annual changes in unemployment rates in treatment groups versus control groups in $\mathrm{AB}$ and $\mathrm{BC}$. During the decade before the E-LMO pilot project implementation, treatment groups experimented relatively small differences in variations from control groups. By 2007, unemployment stopped declining and with the implementation of the pilot project during the 2008-recession, the increase for treatment groups was much larger than for control groups. In addition, the difference in unemployment changes between the two groups was much larger than during the previous recession (i.e., 0.92 in 2009 versus 0.36 in 2002). It had always been below half a percentage point in the non-experiment period (i.e., before E-LMO). So the variability in unemployment rate changes for treatment groups used to be slightly larger but the E-LMO pilot project increased it significantly.

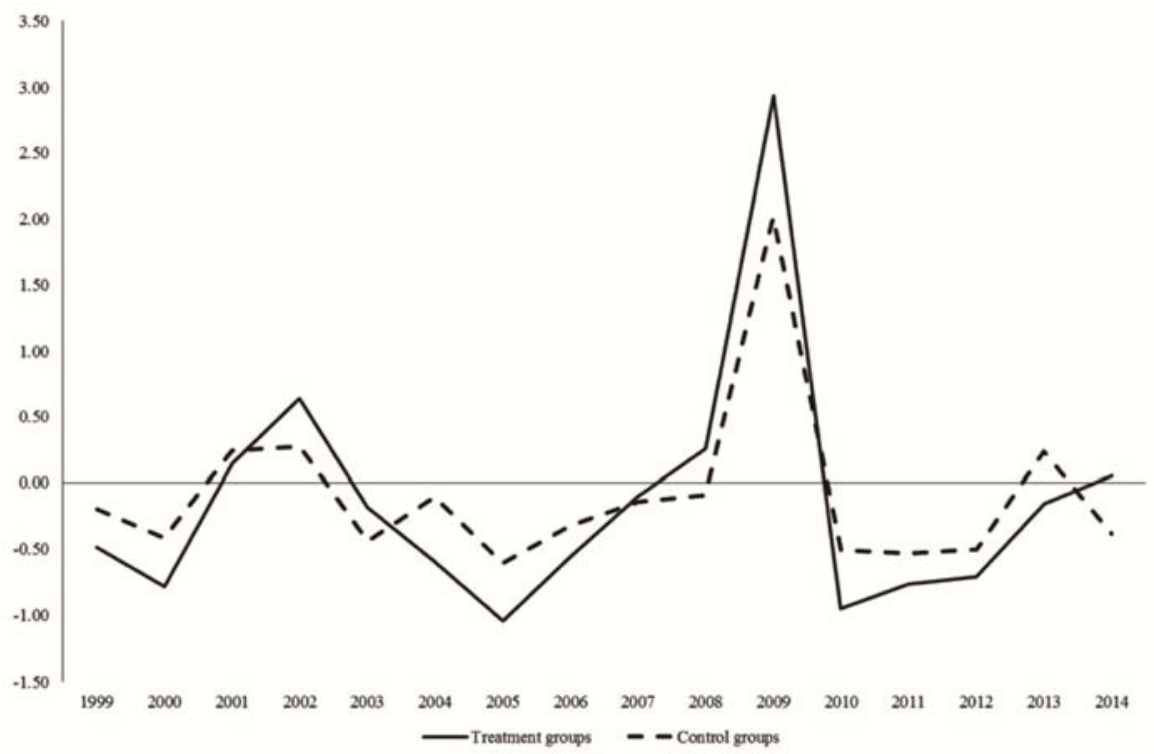

Figure 3. Annual changes in unemployment rates in the experiment region $(B C+A B)$

Source: Statistics Canada (2013a), Table 2820010.

Figure 4 shows annual changes in unemployment rates for treatment groups in the experiment and non-experiment regions. Since 2003, decreases in unemployment rates became a bit larger in the experiment region which is consistent with the faster drop in overall unemployment rates mentioned in Section 3. But with the E-LMO pilot project, in 2008, the rise in unemployment rate in the experiment region was $0.26 \%$ compared to $0.07 \%$ in the rest of the country for treatment groups. By 2009, the difference in rises was 1.09 percentage 


\section{Macrothink}

points. At the end of the project, in 2010-2011, changes were again similar to what they were in the previous economic slowdown from 2002.

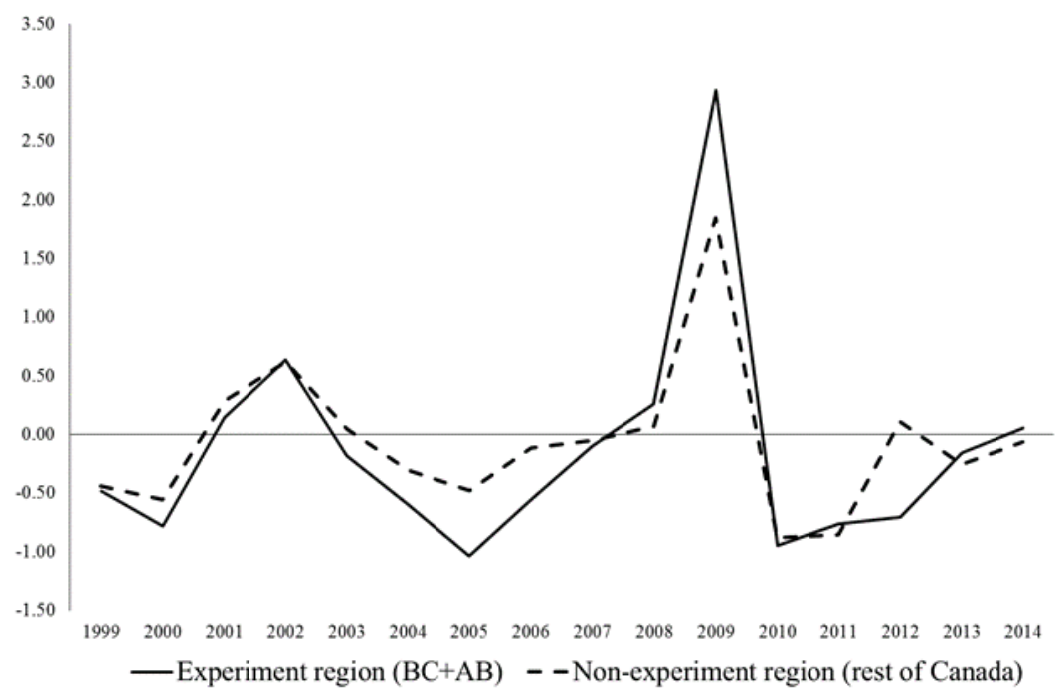

Source: Statistics Canada (2013a), Table 2820010

Figure 4. Annual changes in unemployment rates for treatment groups in both regions

In short, before the experiment period the evolutions of unemployment rates were quite similar but it was slightly larger for the treatment groups. In natural experiment analysis the Difference-in-Difference-in-Difference (DDD) model allows control for these potential differences. Thus, it is used to identify whether the largest rises in unemployment between 2007 and 2010 were due to the E-LMO pilot project in AB and BC. Data conditions for the validity of this methodology are first evaluated.

\section{Experiment Data}

The 33 E-LMO listed occupations are statistically classified in minor groups which are collections of jobs based on the "kind of work performed" with aggregation priority to fields of work for skill types (Statistics Canada, 2006, Introduction). Because there is a constraint on the minimum of published labor market levels, (Note 7) consistent cross-sectional and inter-temporal data exist only for sums of minor groups. Consequently statistics for the analysis at provincial levels cover 25 groups with 12 including E-LMO listed occupations which make up the treatment category. The other 13 make up the control category.

In a standard experiment process, treatment is randomly assigned but this is rarely the case in natural experiments related to policy changes. Main characteristics of the treatment and the control category before and during the policy change should be similar to ensure no bias in the conclusions. In addition, some characteristics of the treatment group must be similar in the experiment and the non-experiment region. So, degrees of similarities are evaluated 
through employers' familiarity with the TFW program in the experiment and non-experiment regions and consistency of E-LMO components in treatment groups in the experiment region and, across the two regions.

First, employers' familiarity with the TFW program is captured by the employment intensity rate from TFWs (Table 2). In 2006, intensity in most non-experiment provinces was lower than in the experiment region as there were between 3.1 and 5.8 employed TFWs per thousand workers against 16.3 in $\mathrm{BC}$ and 11.5 in AB. However, one province (Ontario) had a rate close to $\mathrm{AB}$ with 11.1. During the E-LMO implementation, the rate of TFW employment rose also substantially in the non-experiment provinces. It increased by $226.5 \%$ and $154.9 \%$ in two provinces versus $149.4 \%$ in $\mathrm{AB}$; and, four provinces exhibited a larger increase than $\mathrm{BC}$ at $83.9 \%$. So it can be stated that employers in non-experiment provinces were relying on the TFW program and it was familiar.

Table 2. TFWs levels and intensities in provinces

\begin{tabular}{|l|l|l|l|l|l|}
\hline \multirow{2}{*}{} & \multicolumn{2}{|l}{ TFW levels } & \multicolumn{2}{l|}{$\begin{array}{l}\text { TFW intensity } \\
\text { (TFWs per 1 000 employed) }\end{array}$} & $\begin{array}{l}\text { \% change in } \\
\text { intensity }\end{array}$ \\
\cline { 2 - 6 } & $\mathbf{2 0 0 6}$ & $\mathbf{2 0 1 0}$ & $\mathbf{2 0 0 6}$ & $\mathbf{2 0 1 0}$ & $\mathbf{2 0 0 6 - 2 0 1 0}$ \\
\hline Non-experiment provinces & \multicolumn{5}{l}{} \\
\hline Newfoundland and Labrador & 914 & 1393 & 4.3 & 6.4 & 49.2 \\
\hline Prince Edward Island & 213 & 720 & 3.1 & 10.2 & 226.5 \\
\hline Nova Scotia & 1709 & 3628 & 3.9 & 8.0 & 106.9 \\
\hline New Brunswick & 1109 & 2401 & 3.2 & 6.7 & 113.0 \\
\hline Quebec & 21545 & 34942 & 5.8 & 8.9 & 55.0 \\
\hline Ontario & 71809 & 99932 & 11.1 & 15.1 & 35.8 \\
\hline Manitoba & 3286 & 5047 & 5.6 & 8.1 & 45.8 \\
\hline Saskatchewan & 2167 & 5882 & 4.4 & 11.2 & 154.9 \\
\hline Experiment provinces & & & & & \\
\hline Alberta (AB) & 21979 & 57675 & 11.5 & 28.6 & 149.4 \\
\hline British Columbia (BC) & 35072 & 67770 & 16.3 & 30.0 & 83.9 \\
\hline
\end{tabular}

Sources: CIC (2013); Statistics Canada (2013a), Table 2820010.

Second, consistency in shares of E-LMO occupation units in treatment groups in the experiment region is not evident. In Figure 5, based on labor force data from the 2006-census (Statistics Canada, 2013b), the smallest share is in D2-D3 (group with listed Dental Technicians) with $2.2 \%$ (2.4\% for $\mathrm{AB}$ and $2.1 \%$ for $\mathrm{BC}$ ). Six groups are above $44 \%$ and one low-skill group (J3, Manufacturing and Processing Labourers) covers all listed E-LMO occupations (i.e., 100\%). As a consequence, the potential magnitude of the impact of the E-LMO pilot project is expected to be affected by the different degrees of intensity (Meyer, 1995) within the experiment region. 


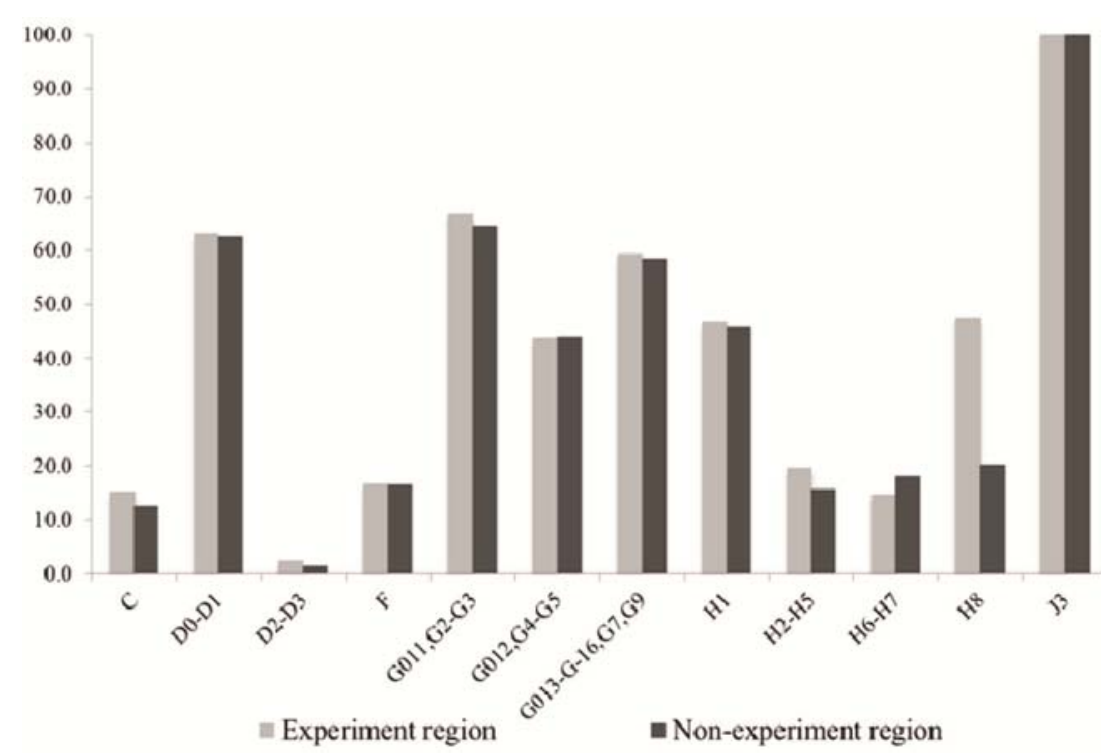

Figure 5. Shares of E-LMO occupation units in treatment groups

Source: Statistics Canada (2013b).

Third, consistency in shares of E-LMO occupation units in treatment groups for the two regions is clear. In Figure 5 there is no major difference between the two regions except in one case, Construction Labourers, Surveyor Helper (H8). Nevertheless, among coefficients of variation across provinces, only one is above 0.25 (0.43 for D2-D3). So, overall there is no significant difference in the distribution of treatment groups for the two regions.

In summary, the potential issue is that shares of E-LMO occupations are quite different within treatment groups while mostly similar across experiment and non-experiment regions. This may generate biases in the results. However, the availability of several treatment groups helps reducing potential biases (Meyer, 1995) and allows for the testing of sensitivity (Rosenbaum, 1987). Thus, the E-LMO pilot project can be a natural experiment, providing there are robustness tests.

\section{Model and Impact of the Experiment}

The DDD model estimates the potential impact of the E-LMO pilot project on resident workers' changes in unemployment rates. There are three dimensions involving levels of interactions which correct for potential differences across groups and regions and, the highest one captures the policy effect (Meyer, 1995). Then the specification is

$$
\begin{aligned}
\text { urate } \left._{i, t}^{j}-\text { urate }_{i, t-1}^{j}\right) & =\alpha_{0}^{j}+\alpha_{1, t}+\alpha_{2} D_{t g}+\alpha_{3}\left(D^{e p} * D_{t}\right)+\alpha_{4}\left(D_{t g} * D_{t}\right) \\
& +\alpha_{5}\left(D^{e p} * D_{t g} * D_{t}\right)+\varepsilon_{i, t}^{j},
\end{aligned}
$$

with urate $_{i, t}^{j}$, the unemployment rate in province $j$ for occupation group $i$ at year $t$. There are two experiment and eight non-experiment provinces with a total of 186 occupation groups (102 for treatment and 84 for control). (Note 8) The period starts in 2002 when the TFW 
program became available for low-skill workers and the last year is 2010. During the period, there are no changes other than the pilot project. The next major change happened in April 2011 with the increase in possible stay for low-skill TFWs from 2 to 4 years (Section 2). Hence, the period lengths before (2003-2006) and during (2007-2010) the experiment are equal.

The impact of the E-LMO pilot project is estimated on unemployment rate changes (urate $_{i, t}^{j}-$ urate $_{i, t-1}^{j}$ )rather than levels because of non-stationarity. The panel estimation includes province fixed effects $\left(\alpha_{0}^{j}\right)$ and year fixed effects $\left(\alpha_{1, t}\right)$ which control for different cross-sectional and inter-temporal economic changes. The main potential cases are the 2008-international financial crisis and, the fact that AB's and BC's economies are more based on natural resources than others. This may be the reason for the slightly higher variability in unemployment rate changes described in Section 3. $D_{t g}$ is the dummy for the treatment groups; $D_{t}$, for E-LMO pilot project period; and $D^{e p}$, for the experiment provinces (see Appendix 1 for details). Then, $D^{e p} * D_{t}$ and, $D_{t g}{ }^{*} D_{t}$ capture project-period specific effects for experiment provinces and for treatment groups. Finally, the interaction of the three variables, $D^{e p} * D_{t g} * D_{t}$, captures effects of the E-LMO pilot project on treatment groups in experiment provinces. If easier access to TFWs through the experiment has had adverse effects on unemployment changes its coefficient $\left(\alpha_{5}\right)$ is positive and significant. Standard errors are corrected for potential clusters across occupations and there is no positive serial correlation.

\subsection{E-LMO Impact}

In Table 3, column 1, the basic DDD identifies a positive impact of the E-LMO project on changes in unemployment in $\mathrm{BC}$ and $\mathrm{AB}$ with an average of 0.729 percentage point per year. Then, some sensitivity tests are done since sample groups are not perfectly random. When occupation group fixed effects substitute province fixed effects, the fit is much weaker and the impact is larger (column 2). This is potentially due to a lack of provincial controls for the variabilities in unemployment rates shown in Section 3. In column 3, where the level of unemployment rates is used, there is a large auto-regressive relation (0.933) confirming that first differences ensure control for non-stationarity. There are some provincial labor market institutions which have been shown to influence unemployment (see for examples, Gross \& Schmitt, 2012; Cousineau \& Vaillancourt, 2001). In column 4, variations in three are controlled for: Employment Insurance (EI) qualification (EIqual), unionization rate (Unionrate) and minimum wages (Minwage). To qualify for EI benefits, the number of weeks of insurable employment is determined by past economic states (Gross \& Schmitt, 2012). As provincial economies evolved radically it is significant. Changes in unionization rates are weakly significant (10\%) and changes in minimum wages are not.

Since the intensity of E-LMO eligible occupations in groups is variable, the potential result bias is tested. A larger share within a group is expected to generate a larger impact. In column 5 , only the seven most intense groups, i.e., with more than $45 \%$ of the labor force with E-LMO occupations are considered and, the policy change impact is larger (i.e., 0.968 versus 0.729). In the whole sample, when each treatment group is controlled for by its weight of listed occupations rather than a dummy (column 6), the impact is also larger (i.e., 1.243). 
Hence, due to lack of micro statistics, there may be some bias in the magnitude of increases in unemployment from the pilot project but the result is likely to be smaller.

Table 3. E-LMOs and changes in unemployment rates

\begin{tabular}{|c|c|c|c|c|c|c|}
\hline & 1. & 2. & 3. & 4. & 5. & 6. \\
\hline & $\begin{array}{l}\text { Province } \\
\text { fixed effects }\end{array}$ & $\begin{array}{l}\text { Occupationfi } \\
\text { xed effects }\end{array}$ & $\begin{array}{l}\text { Unemploy- } \\
\text { ment rates }\end{array}$ & $\begin{array}{l}\text { Provinces } \\
\text { institutions }\end{array}$ & $\begin{array}{l}\text { High density } \\
\text { treatment } \\
\text { groups }\end{array}$ & $\begin{array}{l}\text { Weighted } \\
\text { treatment } \\
\text { groups }\end{array}$ \\
\hline$D_{\operatorname{tg}}$ & $\begin{array}{l}-0.259 \\
(0.17)\end{array}$ & - & $\begin{array}{l}-0.031 \\
(0.17)\end{array}$ & $\begin{array}{l}-0.258 \\
(0.17)\end{array}$ & $\begin{array}{l}-0.354 \\
(0.22)\end{array}$ & $\begin{array}{l}-0.566 * * \\
(0.30)\end{array}$ \\
\hline$D^{e p} * D_{t}$ & $\begin{array}{l}0.751^{* *} \\
(0.37)\end{array}$ & $\begin{array}{l}0.557 \\
(0.39)\end{array}$ & $\begin{array}{l}0.777 * * \\
(0.36)\end{array}$ & $\begin{array}{l}0.595^{* * *} \\
(0.18)\end{array}$ & $\begin{array}{l}0.575^{* * *} \\
(0.21)\end{array}$ & $\begin{array}{l}0.765^{* * *} \\
(0.20)\end{array}$ \\
\hline$D_{t g} * D_{t}$ & $\begin{array}{l}0.603 \\
(0.49)\end{array}$ & $\begin{array}{l}0.531 \\
(0.53)\end{array}$ & $\begin{array}{l}0.567 \\
(0.49)\end{array}$ & $\begin{array}{l}0.600 \\
(0.49)\end{array}$ & $\begin{array}{l}0.866 \\
(0.59)\end{array}$ & $\begin{array}{l}1.461^{* *} \\
(0.73)\end{array}$ \\
\hline$D^{e p *} D_{t g} * D_{t}$ & $\begin{array}{l}0.729 * * * \\
(0.10)\end{array}$ & $\begin{array}{l}1.086^{* * *} \\
(0.16)\end{array}$ & $\begin{array}{l}0.627 * * * \\
(0.13)\end{array}$ & $\begin{array}{l}0.739 * * * \\
(0.10)\end{array}$ & $\begin{array}{l}0.968^{* * *} \\
(0.16)\end{array}$ & $\begin{array}{l}1.243^{* * *} \\
(0.27)\end{array}$ \\
\hline$d$ (EIqual) & - & - & - & $\begin{array}{l}-0.361^{* * *} \\
(0.04)\end{array}$ & $\begin{array}{l}-0.334 * * * \\
(0.05)\end{array}$ & $\begin{array}{l}-0.355^{* * *} \\
(0.04)\end{array}$ \\
\hline$d$ (Unionrate) & - & - & - & $\begin{array}{l}0.101 * \\
(0.06)\end{array}$ & $\begin{array}{l}0.105^{*} \\
(0.06)\end{array}$ & $\begin{array}{l}0.102 * * \\
(0.05)\end{array}$ \\
\hline dln(Minwage) & - & - & - & $\begin{array}{l}0.219 \\
(1.43)\end{array}$ & - & - \\
\hline Urate $_{t-1}$ & - & - & $\begin{array}{l}0.933 * * * \\
(0.03)\end{array}$ & - & - & - \\
\hline $\begin{array}{l}\text { Province fixed } \\
\text { effects }\end{array}$ & Yes & No & Yes & Yes & Yes & Yes \\
\hline $\begin{array}{l}\text { Year fixed } \\
\text { effects }\end{array}$ & Yes & Yes & Yes & Yes & Yes & Yes \\
\hline $\begin{array}{l}\text { Occupation } \\
\text { fixed effects }\end{array}$ & No & Yes & No & No & No & No \\
\hline Adjusted $\mathrm{R}^{2}$ & 0.135 & 0.030 & 0.922 & 0.144 & 0.135 & 0.148 \\
\hline $\mathrm{n}$ & 186 & 186 & 186 & 186 & 143 & 186 \\
\hline $\mathrm{t}$ & 8 & 8 & 8 & 8 & 8 & 8 \\
\hline
\end{tabular}

Note. White cross-section S.E. are in parentheses with *, **, *** for significance at $10 \%, 5 \%$ and $1 \%$.

Finally, the model is estimated with geographical aspects (Table 4). First, the non-experiment region is limited to Prairies provinces (Saskatchewan and Manitoba), because they have similar economic structures and unemployment rates to the experiment provinces. (Note 9) The acceleration of unemployment in the experiment region has been faster when compared to the economically similar non-experiment region (0.903 versus 0.729$)$. Second, specific 
effects for $\mathrm{BC}$ and $\mathrm{AB}$ are estimated and, the impact in $\mathrm{BC}$ has been more than twice the one in $\mathrm{AB}$ (0.965 versus 0.447, with a t-value of 5.99 for the difference). Before the implementation of the E-LMO pilot project, unemployment rates for treatment groups were lower in $\mathrm{AB}$ than in $\mathrm{BC}$ (Table 1) indicating more labor shortages; yet, relatively less positions were confirmed in 2007 and 2008 by E-LMOs in AB.(Note 10) So, this is consistent with employers in BC having strong recourse to TFWs despite lacks of systematic deep labor shortages.

Table 4. E-LMOs in geographical contexts

\begin{tabular}{|c|c|c|}
\hline & Prairies provinces & Separate AB and BC \\
\hline$D_{t g}$ & $\begin{array}{l}-0.373^{* * *} \\
(0.13)\end{array}$ & $\begin{array}{l}-0.259 \\
(0.17) \\
\end{array}$ \\
\hline$D^{e p *} D_{t}$ & $\begin{array}{l}0.685^{* * *} \\
(0.22)\end{array}$ & - \\
\hline$A B * D_{t}$ & - & $\begin{array}{l}0.658^{* * *} \\
(0.26)\end{array}$ \\
\hline$B C^{*} D_{t}$ & - & $\begin{array}{l}0.562 * * * \\
(0.17)\end{array}$ \\
\hline$D_{t g} * D_{t}$ & $\begin{array}{l}0.570 \\
(0.37) \\
\end{array}$ & $\begin{array}{l}0.601 \\
(0.49) \\
\end{array}$ \\
\hline$D^{e p} * D_{t g} * D_{t}$ & $\begin{array}{l}0.903^{* * *} \\
(0.25) \\
\end{array}$ & - \\
\hline$A B^{*} D_{t g} * D_{t}$ & - & $\begin{array}{l}0.447 * * * \\
(0.11)\end{array}$ \\
\hline$B C^{*} D_{t g} * D_{t}$ & - & $\begin{array}{l}0.965^{* * *} \\
(0.10)\end{array}$ \\
\hline$d($ EIqual $)$ & $\begin{array}{l}-0.346^{* * *} \\
(0.11)\end{array}$ & $\begin{array}{l}-0.352^{* *} \\
(0.04)\end{array}$ \\
\hline$d$ (Unionrate) & $\begin{array}{l}0.078 \\
(0.07) \\
\end{array}$ & $\begin{array}{l}0.104^{* *} \\
(0.06) \\
\end{array}$ \\
\hline Fixed provincial effects & Yes & Yes \\
\hline Fixed year effects & Yes & Yes \\
\hline Fixed occupation effects & No & No \\
\hline Adjusted $\mathrm{R}^{2}$ & 0.313 & 0.144 \\
\hline $\mathrm{n}$ & 70 & 186 \\
\hline $\mathrm{t}$ & 8 & 8 \\
\hline
\end{tabular}

Based on these results, business pressures to get easier access to TFWs were not linked to labor shortages. Thus, while there were low unemployment rates for some groups, the list of occupations was not set-up correctly to avoid negative impacts on resident workers. 


\subsection{Occupations Wrongly Listed}

To identify the wrongly listed occupations, effects on the six occupational treatment groups ( $k=1$ to 6$)$ are estimated for each of the two treatment provinces $(t=1,2)$ with the model,

$$
\begin{aligned}
\text { urate } \left._{i, t}^{j}-\text { urate }_{i, t-1}^{j}\right) & =\alpha_{0}^{j}+\alpha_{1, t}+\sum_{k} \sum_{t} \alpha_{2, k, t} D_{t g, k}+\sum_{t} \alpha_{3}\left(D^{e p} * D_{t}\right)+\sum_{k} \sum_{t} \alpha_{4, k, t}\left(D_{t g, k} * D_{t}\right) \\
& +\sum_{k} \sum_{t} \alpha_{5, k, t}\left(D^{e p} * D_{t g, k} * D_{t}\right)+\varepsilon_{i, t}^{j} .
\end{aligned}
$$

Overall, the E-LMO project has had very different impacts on occupation groups (Table 5).

\begin{tabular}{|c|c|c|c|c|}
\hline & \multicolumn{2}{|c|}{$\begin{array}{l}A B \text { and } B C \text { vs rest of } \\
\text { the country }\end{array}$} & $\begin{array}{l}\text { AB vs rest of the } \\
\text { country }\end{array}$ & $\begin{array}{l}\text { BC vs rest of } \\
\text { the country }\end{array}$ \\
\hline & \multicolumn{2}{|l|}{1.} & 2. & 3. \\
\hline \multirow{2}{*}{$\begin{array}{l}\text { Natural and Applied Sciences and Related } \\
\text { Occupations }(C)\end{array}$} & $\mathrm{AB}$ & $\begin{array}{l}0.281 \\
(0.80)\end{array}$ & \multirow{2}{*}{$\begin{array}{l}0.279 \\
(0.79)\end{array}$} & \multirow{2}{*}{$\begin{array}{l}0.447 \\
(0.94)\end{array}$} \\
\hline & $\mathrm{BC}$ & $\begin{array}{l}0.449 \\
(0.94)\end{array}$ & & \\
\hline \multirow[b]{2}{*}{ Health Occupations (D) } & $\mathrm{AB}$ & n.a. & \multirow[b]{2}{*}{ n.a. } & \multirow{2}{*}{$\begin{array}{l}0.010 \\
(0.13)\end{array}$} \\
\hline & $\mathrm{BC}$ & $\begin{array}{l}-0.004 \\
(0.15)\end{array}$ & & \\
\hline \multirow{2}{*}{$\begin{array}{l}\text { Occupations in Art, Culture, Recreation and } \\
\text { Sports (F) }\end{array}$} & $\mathrm{AB}$ & $\begin{array}{l}-0.464 \\
(0.71)\end{array}$ & \multirow{2}{*}{$\begin{array}{l}-0.448 \\
(.71)\end{array}$} & \multirow{2}{*}{$\begin{array}{l}0.037 \\
(0.78)\end{array}$} \\
\hline & $\mathrm{BC}$ & $\begin{array}{l}0.022 \\
(0.78)\end{array}$ & & \\
\hline \multirow{2}{*}{ Sales and Service Occupations $(G)$} & $\mathrm{AB}$ & $\begin{array}{l}-0.094 \\
(0.31)\end{array}$ & \multirow{2}{*}{$\begin{array}{l}-0.096 \\
(0.32)\end{array}$} & \multirow{2}{*}{$\begin{array}{l}0.045 \\
(0.21)\end{array}$} \\
\hline & $\mathrm{BC}$ & $\begin{array}{l}0.047 \\
(0.21)\end{array}$ & & \\
\hline \multirow{2}{*}{$\begin{array}{l}\text { Trades, Transport and Equipment Operators } \\
\text { and Related Occupations }(H)\end{array}$} & & $\begin{array}{l}1.260^{* * *} \\
(0.31)\end{array}$ & \multirow{2}{*}{-} & \multirow{2}{*}{ - } \\
\hline & BC & $\begin{array}{l}2.451^{* * *} \\
(0.34)\end{array}$ & & \\
\hline Construction Trades (H1) & \multicolumn{2}{|l|}{-} & $\begin{array}{l}1.233 \\
(1.50)\end{array}$ & $\begin{array}{l}2.990^{* * *} \\
(0.76)\end{array}$ \\
\hline Engineers, Machinists, Mechanics, Other & \multicolumn{2}{|l|}{-} & 0.386 & $0.931 * * *$ \\
\hline Heavy Equipment and Transportation & \multicolumn{2}{|l|}{-} & 0.932 & $2.006^{* * *}$ \\
\hline Operators $(H 6-H 7)$ & \multirow{3}{*}{\multicolumn{2}{|c|}{-}} & $(0.80)$ & $(0.61)$ \\
\hline Trade Helpers, Construction and & & & $2.480^{* *}$ & $3.872 * * *$ \\
\hline Transportation Labourers (H8) & & & $(1.23)$ & $(0.54)$ \\
\hline
\end{tabular}

Table 5. E-LMOs on specific treatment groups 


\begin{tabular}{|l|ll|l|l|}
\hline \multirow{2}{*}{$\begin{array}{l}\text { Occupations Unique to Processing, } \\
\text { Manufacturing, Utilities (J) }\end{array}$} & AB & & \multirow{2}{*}{\begin{tabular}{l} 
n.a. \\
\cline { 2 - 4 }
\end{tabular}} \\
\cline { 2 - 4 } & BC & $\begin{array}{l}0.498 \\
(0.44)\end{array}$ & & $(0.44)$ \\
\hline $\mathrm{n}$ & 186 & 165 & 170 \\
\hline $\mathrm{t}$ & 8 & 8 & 8 \\
\hline Adjusted R & 0.146 & 0.117 & 0.136 \\
\hline
\end{tabular}

Note. All estimations have occupation and year fixed effects and control for provincial institutions. White cross-section S.E. are in parentheses with *, **, *** for significance at $10 \%, 5 \%$ and $1 \%$.

In column 1, unemployment in both provinces has raised significantly faster only in Trades, Transport and Equipment Operators and Related Occupations (H). The impact in BC has been again almost twice the one in AB (2.451 versus 1.260). Since occupational components for this group are available, Columns 2 and 3 show specific effects for each experiment province versus the rest of Canada. In $\mathrm{AB}$ the adverse impact occurred only on the lowest skilled group (H8) and the effect is much smaller than in BC (2.480 versus 3.872$)$. This low-skill occupation group is in construction and transport and had $10.4 \%$ unemployment (Table 1). Barnetson \& Foster (2014), 352, indicate that "Alberta construction employers have reported that TFWs are preferable because they are more compliant and productive than permanent residents." Yet, the group Labourers in Manufacturing (J) with only low-skill levels and a similar unemployment rate before the E-LMO project (10.8\%) has not been affected significantly in either province. This confirms that specific business pressures played a role in requests for easier access to TFWs independently of labor shortages.

In BC, both high-skill occupation groups in $H$ have been affected: $H 2-H 5$ with 0.931 , the lowest significant impact and $H 1$ with 2.990. The reason may be coverage of different industries. Like low-skill H8 with the largest impact (3.872), H1 covers construction occupations; H2-H5 is transport and equipment operators (Statistics Canada, 2013b). For BC, there is some evidence that local construction workers were worried about TFW hiring. In the fall of 2008, 43.8\% of surveyed construction workers in the city of Vancouver (58\% of low-skill) believed TFWs made it harder for them to find jobs and, 46.2\% (64\% of low-skill) thought TFWs were not needed (Gross, 2011, Tables 5 and 8).

Given these specific significant effects, the cost on unemployment for the two provinces are assessed. In Table 6, for the only affected low-skill group in Alberta, up to 1262 people annually became unemployed due to the E-LMO pilot project. And, in 2008, the highest unemployment rate without TFWs could have been 15.5\% instead of 18\% (2.5 percentage points). In BC, more than 7000 people have been affected annually in the whole H-group and the unemployment rate would have been $9.3 \%$ instead of $11.5 \%$ in 2009 . In $H 8$, the loss of unemployment was 3.9 percentage points in 2008-2009. Hence, the E-LMO project has definitely been less costly for local workers in $\mathrm{AB}$ than in BC. 
Table 6. Impact on unemployment of the E-LMO pilot project

\begin{tabular}{|l|l|l|l|l|l|l|l|l|l|}
\hline & \multicolumn{9}{|l|}{ Alberta } \\
\cline { 2 - 10 } & H8 & \multicolumn{2}{l|}{ H8 } & \multicolumn{2}{l|}{ (H1, H2H5, H6H7) } \\
\cline { 2 - 11 } & $\begin{array}{l}\text { Estimated } \\
\text { impact }\end{array}$ & $\begin{array}{l}\text { Adjusted } \\
\text { unemp. } \\
\text { rate }\end{array}$ & $\begin{array}{l}\text { Actual } \\
\text { unemp. } \\
\text { rate }\end{array}$ & $\begin{array}{l}\text { Estimated } \\
\text { impact }\end{array}$ & $\begin{array}{l}\text { Adjusted } \\
\text { unemp. } \\
\text { rate }\end{array}$ & $\begin{array}{l}\text { Actual } \\
\text { unemp. } \\
\text { rate }\end{array}$ & $\begin{array}{l}\text { Estimated } \\
\text { impact }\end{array}$ & $\begin{array}{l}\text { Adjusted } \\
\text { unemp. } \\
\text { rate }\end{array}$ & $\begin{array}{l}\text { Actual } \\
\text { unemp. } \\
\text { rate }\end{array}$ \\
\hline $\mathbf{2 0 0 6}$ & - & 8.2 & 8.2 & - & 8.3 & 8.3 & - & 3.4 & 3.4 \\
\hline $\begin{array}{l}\mathbf{2 0 0 7} \\
\text { (Sep-Dec) }\end{array}$ & 309 & 6.6 & 7.2 & 499 & 5.3 & 6.3 & 1234 & 2.4 & 2.8 \\
\hline $\mathbf{2 0 0 8}$ & 1262 & 6.6 & 9.1 & 2137 & 5.7 & 9.6 & 5294 & 2.3 & 4.2 \\
\hline $\mathbf{2 0 0 9}$ & 1188 & 15.5 & 18.0 & 2176 & 14.7 & 18.6 & 5133 & 8.1 & 10.0 \\
\hline $\begin{array}{l}\mathbf{2 0 1 0} \\
\text { (Jan-Apr) }\end{array}$ & 337 & 10.5 & 11.1 & 463 & 17.3 & 18.3 & 1307 & 7.0 & 7.5 \\
\hline
\end{tabular}

It is somewhat surprising that workers in the construction industry have been penalized. Between 2007 and 2010, forecasts for the next three years in BC indicated a systematic rise in excess supply of labor for the listed E-LMO construction occupations by about 2 to 4.5 percentage points (Construction Sector Council, 2008). However, these predictions may not have been trusted as there have been criticisms about the lack of adequate measures for labor demand and supply for occupations and locally (Foot \& Meltz, 1992; Smith, 2002; Drummond et al., 2009; Lefebvre et al., 2012).In addition, there have been confirmations that federal agencies lack adequate processes to check the validity of employer's LMOs (Auditor General of Canada, 2009; Barnetson \& Foster, 2014). The E-LMO pilot project that gave a very attractive short processing time to employers was not implemented under two required conditions for efficiency of the TFW program: perfect identification of labor shortages and regular review of the occupation list (Chaloff \& Lemaître, 2009). In summary, the E-LMO pilot project was not suitably implemented geographically and occupationally. Then, some businesses took the opportunity to hire TFWs to lower their employment costs which was politically accepted.

\section{Conclusion}

The goal of TFW program is to smooth short-term economic activities by allowing employers to access the world supply of workers relatively easily. Yet, the long-term goal must be to increase productivity in those occupations through improved technologies or training in order to avoid degenerating social status of these jobs (Castles, 2006). This is achieved only if priority is systematically given to domestic workers with the offer of training and appropriate wages. An adequately designed and implemented list of eligible occupations for TFWs with less time-consuming constraints for employers can ensure it; but the necessary condition is perfect identification of occupational labor shortages and strict implementation.

Canada responded to business pressures with the E-LMO pilot project for two provinces which dropped the time to obtain approval for hiring TFWs from five months to five days. 
Yet, between 2007 and 2010, this experiment accelerated the rise in unemployment of some high- and low-skill workers. Clearly some employers did not give priority to domestic workers even when the unemployment rate was above $10 \%$ and when forecasted labor supply was rising.

A TFW program, with or without strong constraints, requires acute knowledge on types and locations of labor shortages. This has been a typical Canadian shortcoming. The government often was simply agreeing with employers who pressured to simplify the process, even though there were signals that labor shortages were not obvious. In addition, legal wages to be paid to TFWs were lower than those necessary to attract local workers and there was a strong incentive for employers to keep claiming needs for TFWs. In Canada the E-LMO pilot project was a policy change in favor of businesses with a cost to domestic workers and the recession, following the 2008-crisis stopped it. While stimulating economic growth in the medium-term is positive, a TFW program should not be used for that purpose. By definition, it is a policy for short-term business difficulties.

\section{Acknowledgement}

I do thank participants at the presentation for the 2014 Canadian Economic Meeting in Vancouver and those at the SFU School of Public Policy seminar for their useful comments. I also thank supporting readers and anonymous referees.

\section{References}

Auditor General of Canada. (2009). Selecting Foreign Workers under the Immigration Program. Report of the Auditor General of Canada to the House of Commons. Chap. 2. Fall.

Barnetson, B., \& Foster, J. (2014). The Political Justification of Migrant Workers in Alberta, Canada. Journal of International Migration and Integration, 15, 349-370. http://dx.doi.org/10.1007/s12134-013-0292-6.

Beine, M. A. R., \& Coulombe, S. (2014). Immigration and Internal Mobility in Canada. CESifo Working Paper Series. No 4823. [Online] Available: https://ssrn.com/abstract=2461625

Bourgeois, A., Debus, A., George, B., Halbesma, J., Kelly, D., Langford, J., \& Lavoie, A. (2006). Immigration and Small Business: Ideas to Better Respond to Canada's Skills and Labour Shortage. Willowdale, Ontario: Canadian Federation of Independent Business.

Castles, S. (2006). Guestworkers in Europe: A Resurrection? International Migration Review, 40(4), 741-766. http://dx.doi.org/10.1111/j.1747-7379.2006.00042.x

Chaloff J., \& Lemaître, G. (2009). Managing Highly-Skilled Labour Migration: A Comparative Analysis of Migration Policies and Challenges in OECD Countries. OECD Social, Employment and Migration Working Papers. No 79. Paris: OECD publishing.

CIC, Citizenship and Immigration Canada. (2010). Backgrounders-Improvements to the Temporary Foreign Worker Program. [Online] Available: http://www.cic.gc.ca/english/department/media/backgrounders/2010/2010-08-18.asp 
CIC. (2011). Backgrounder-Four-Year Limit for Foreign Nationals Working in Canada. [Online] Available: http://www.cic.gc.ca/english/department/media/backgrounders/2011/2011-03-24.asp

CIC. (2013). Canada Facts and Figures. Immigration Overview. Permanent and Temporary Residents. 2012. Ottawa.

CIC. (2015). Canada Facts and Figures. Immigration Overview. Temporary Residents. 2014. Ottawa.

CNC, Canada News Centre. (2007a). Occupations under Pressure Lists Fast-Track Temporary Foreign Workers Hires. November 26. Government of Canada. [Online] Available: http://www.cicnews.com/2007/11/occupations-pressure-lists-fasttrack-temporary-foreign-wor ker-hires-11298.html

CNC. (2007b). Temporary Foreign Worker Program Improved for Employers in B.C. and Alberta. September 24. Government of Canada. [Online] Available: http://news.gc.ca/web/article-eng.do?nid=350829

CNC. (2008). Government of Canada Announces Expansion of Temporary Foreign Worker Program Pilot Project to Ease Labour Shortages for Employers in B.C. and Alberta. January 14. Government of Canada. [Online] Available: http://news.gc.ca/web/article-eng.do?nid=371869

Construction Sector Council. (2008). Construction Looking Forward. Labour Requirements for 2007 to 2015 by British Columbia. May. Ottawa.

Cousineau, J. M., \& Vaillancourt, F. (2001). Regional Disparities, Mobility and Labour Markets in Canada. In W. C. Riddell \& F. St-Hilaire (Eds.), Adapting Public Policy to a Labour Market in Transition (pp. 143-174). Montreal, Kingston: McGill-Queen's University Press.

Drummond, D., Beale, E., Kolby, K., Loiselle, M., \& Miner, R. (2009). Working Together to Build a Better Labour Market Information System for Canada. Toronto, Canada: Advisory Panel on Labour Market Information.

Dungan, P., Fang, T. \& Gunderson, M. (2012). Macroeconomic Impacts of Canadian Immigration: Results from a Macro Model. British Journal of Industrial Relations, 51(1), 174-195. http://dx.doi.org/10.1111/j.1467-8543.2012.00905.x.

Dustmann, C., Bentolila S., \& Faini, R. (1996). Return Migration: The European Experience. Economic Policy, 11(22), 213-250. Reviewed work. https://doi.org/10.2307/1344525

Employment and Social Development Canada (ESDC). (2014). Overhauling the Temporary Foreign Worker Program. Putting Canadians First. Ottawa. [Online] Available: http://www.esdc.gc.ca/eng/jobs/foreign_workers/index.shtml

Foot D. K., \& Meltz, N. M. (1992). An Ex Post Evaluation of Canadian Occupational Projections, 1961-1981. Relations Industrielles / Industrial Relations, 47(2), 268-278. 
[Online] Available: http://www.jstor.org/stable/23073834

Fortin, P. (2000). Macroeconomic Unemployment and Structural Unemployment. Canadian Public Policy/Analyse de Politiques, 26, S125-S130. http://dx.doi.org/10.2307/3552507.

Foster, J. (2012). Making Temporary Permanent: The Silent Transformation of the Temporary Foreign Worker Program. Just Labour, 19, 22-46.

Fudge J., \& MacPhail, F. (2009). The Temporary Foreign Worker Program in Canada: Low-Skilled Workers as an Extreme Form of Flexible Labor. Comparative Labor Law and Policy Journal, 31(1), 5-45.

Government of Canada. (2015). Minimum Wage Database. Ottawa. [Online] Available: http://srv116.services.gc.ca/dimt-wid/sm-mw/menu.aspx?lang=eng

Gross, D. M. (2011). Who Feels Economically Threatened by Temporary Foreign Workers? Evidence from the Construction Industry. Economic Papers: A journal of applied economics and policy, 30(4), 530-545. http://dx.doi.org/10.1111/j.1759-3441.2011.00140.x

Gross, D. M., \& Schmitt, N. (2012). Temporary Foreign Workers and Regional Labour Market Disparities in Canada. Canadian Public Policy/Analyse de Politiques, 38(2), 233-263. http://dx.doi.org/10.3138/cpp.38.2.233

House of Commons Canada. (2009). Temporary Foreign Workers and Non-Status Workers. Report on the Standing Committee on Citizenship and Immigration. 40th Parliament, 2nd Session. May.

HRSDC, Human Resources and Skills Development. (2006). National Occupational Classification Matrix. MP53-25/3-2006. Ottawa. [Online] Available: http://noc.esdc.gc.ca/English/noc/Matrix2006.aspx?val=6\&val1=6662\&ver=06

HRSDC. (2008). Government of Canada Announces Expansion of Temporary Foreign Worker Program Pilot Project to Ease Labour Shortages for Employers in B.C. and Alberta. News Releases. Ottawa. [Online] Available: http://news.gc.ca/web/article-en.do?nid=371869

HRSDC. (2013a). Temporary Foreign Worker Program. Ottawa. [Online] Available:http://www.hrsdc.gc.ca/eng/workplaceskills/foreign_workers/index.shtml

HRSDC. (2013b). Temporary foreign worker program. New Wage Structure. Fact sheet. [Online]

Available:

http://www.hrsdc.gc.ca/eng/jobs/foreign_workers/communications/wage.shtm

HRSDC. (2013c). NOC. Occupational Structure by Skill Types. Tutorial. [Online] Available: http://www30.hrsdc.gc.ca/NOC/English/NOC/2006/Tutorial.aspx\#8

HRSDC. (2013d). Temporary Foreign Worker Program. Labour Market Opinion (LMO) Statistics. [Online] Available: http://www.hrsdc.gc.ca/eng/workplaceskills/foreign_workers/stats/archive_stats_list.shtm HRSDC. (2013e). Temporary Foreign Worker Program. Changes to the Temporary Foreign 
Worker Program. Employment and Social Development. Canada. [Online] Available: http://www.hrsdc.gc.ca/eng/jobs/foreign_workers/changes.shtml

Islam, A. (2007). Immigration Unemployment Relationship: The Evidence from Canada. Australian Economic Papers, 46(1), 52-66. [Online] Available: http://onlinelibrary.wiley.com/doi/10.1111/j.1467-8454.2007.00305.x/abstract

Lefebvre, R., Simonova E., \& Wang, L. (2012). Labour Shortages in Skilled Trades-The Best Guestimate? Issue in Focus. July. Ottawa: Certified General Accountant Association of Canada.

Marr, W. L., \& Siklos, P. L. (1995). Immigration and Unemployment: A Canadian Macroeconomic Perspective. In D. DeVoretz (Ed.), Diminishing Returns: The Economics of Canada's Recent Immigration Policy (pp. 293-330). Toronto: C.D. Howe Institute.

Meyer, B. D. (1995). Natural and Quasi-Experiments in Economics. Journal of Business and Economic Statistics, 13(2), 151-161. https://doi.org/10.1080/07350015.1995.10524589

Nakache, D. (2013). The Canadian Temporary Foreign Worker Program: Regulations, Practices and Protection Gaps. In L. Goldring \& P. Landolt (Eds.), Producing and Negotiating Non-Citizenship: Precarious Legal Status in Canada (pp. 71-95). Toronto: University of Toronto Press.

Rheault, L. (2013). Corporate Lobbying and Immigration Policies in Canada. Canadian Journal of Political Science, 46(3), 691-722. https://doi.org/10.1017/S0008423913000644

Rosenbaum, P. R. (1987). The Role of a Second Control Group in an Observational Study. Statistical Science, 2(3), 292-306. https://doi.org/10.1214/ss/1177013232

Ruhs, M. (2006). The potential of temporary migration programmes in future international migration policy. International Labour Review, 145(1-2), 7-36. http://dx.doi.org/10.1111/j.1564-913X.2006.tb00008.x

Smith, D. A. (2002). Forecasting future skill needs in Canada. In M. Neugart \& K. Schömann (Eds.), Forecasting labour markets in OECD countries: measuring and tackling mismatches (pp. 66-79). Cheltenham: Edward Elgar Publishing. https://doi.org/10.4337/9781781950869.00010

Statistics Canada. (2006). National Occupational Classification for Statistics (NOC-S). Catalogue No 12-583 XIE. Standards Division. Ottawa.

Statistics Canada. (2013a). CANSIM. Electronic Database. Ottawa.

Statistics Canada. (2013b). 2006 Census of Population. Ottawa.

Statistics Canada. (2014). Labour Force Survey (LFS). Ottawa.

Tu, J. (2010). The Impact of Immigration on the Labour Market Outcomes of Native-Born Canadians. IZA Discussion Paper No 5129. [Online] Available: https://ssrn.com/abstract=1663169 


\section{Notes}

Note 1. In July 2014, the name became Labour Market Impact Assessment, LMIA (ESDC, 2014). Since the paper mostly covers a period until 2014, the LMO acronym is used.

Note 2. The information is from HRSDC (2013a), Nakache (2013) and Fudge \& MacPhail (2009) unless otherwise indicated.

Note 3. LMO is not required if there is a trade agreement such as the North American Free Trade Agreement or a bilateral agreement with the source country and, if TFWs come through special provincial programs or contribute to Canadian interests. In addition, spouse/partners and research/studies related individuals are also TFWs (ESDC, 2014).

Note 4. The information is from CIC (2010, 2011) and CNC (2007b) unless otherwise indicated.

Note 5. A similar project was introduced in April 2012 for managers and high-skill workers across the whole country and suspended in April 2013 (HRSDC, 2013e).

Note 6. Appendix 1 provides definition of high-, low-skill and the list of occupations with skill levels and groups.

Note 7. The minimum is 1,500 people. Based on 2006-census data, in 20 unit groups from $\mathrm{BC}$ and 22 from $\mathrm{AB}$, out of 33 from the list, 1,500 people would be more than $10 \%$ unemployment (Statistics Canada, 2013b). Details are in Appendix 1.

Note 8. A detailed description of the occupational group components is available upon request.

Note 9. The unemployment rates in Saskatchewan and Manitoba were $5.1 \%$ and $4.8 \%$ in 2005 and 4.7\% and 4.3\% in 2006. For Alberta and British-Columbia they were 4\% and 5.8\% in 2005 and 3.4\% and 4.8\% in 2006 (Statistics Canada, 2013a, Table 2820010).

Note 10. In late 2007 and in 2008, 3.9\% and 30.3\% confirmed TFW positions for high- and low-skill workers were through E-LMOs in BC and 2.2\% and 26.5\%, in Alberta. In 2009 and early 2010, the rates were higher in Alberta than in BC: $22.6 \%$ and $5.4 \%$ versus $10.0 \%$ and 1.3\% (HRSDC, 2013d, Tables 3, 7 and 9).

\section{Appendix 1.}

\section{Occupation distributions for E-LMO.}

Eligible E-LMO occupations are part of the occupation groups categorized by the Canadian National Occupation System (NOC-S). There are four levels: Unit group (3-digit), minor group (2-digit), major group (1-digit), and, components of broad occupational groups (letter). The E-LMO pilot project covered 33 specific occupations defined as unit groups. Labor data are not available if numbers are below 1,500 people (Statistics Canada, 2014).

Skill classes are based on education types: A is university education; B, college education or 
apprenticeship training; C, secondary school and/or occupation-specific training; and, D, usually provided on-the-job training. High-skill is $\mathrm{A}+\mathrm{B}$; low-skill, $\mathrm{C}+\mathrm{D}$. In addition, Class 0 covers managers with no education reference (HRSDC, 2013c).

Table A.1.1. Occupations, skills and groups for treatment category

\begin{tabular}{|c|c|c|}
\hline Broad Occupational Groups & E-LMO Occupation (NOC-S 2006) & Skill class \\
\hline \multirow[t]{2}{*}{$\begin{array}{l}\text { Natural and Applied Sciences and } \\
\text { Related Occupations (C) }\end{array}$} & $\begin{array}{l}\text { Mechanical Engineers (C032), Civil Engineers (C031), } \\
\text { Electrical and Electronics Engineers (C033), Petroleum } \\
\text { Engineers (C045). }\end{array}$ & A \\
\hline & Mechanical Engineering Technologists (C132). & B \\
\hline \multirow{2}{*}{ Health Occupations (D). } & *Registered Nurses (D112), *Pharmacists (D031). & A \\
\hline & *Dental Technicians (D223). & B \\
\hline $\begin{array}{l}\text { Occupations in Art, Culture, } \\
\text { Recreation and Sport (F) }\end{array}$ & *Snowboard and Ski Instructors (F154). & B \\
\hline \multirow{3}{*}{ Sales and Service Occupations (G) } & $\begin{array}{l}\text { Food Service Supervisors (G012), Industrial Meat Cutters } \\
\text { (G941). }\end{array}$ & B \\
\hline & $\begin{array}{l}\text { *Retail Sales Persons and Sales Clerks (G211). *Food and } \\
\text { Beverage Servers (G513), *Hotel and Hospitality Room } \\
\text { Attendants (G732), *Hotel Front Desk Clerks (G715), } \\
\text { *Tour and Travel Guides (G721). }\end{array}$ & C \\
\hline & $\begin{array}{l}\text { *Food Counter Attendants (G961), Commercial Janitors } \\
\text { and Caretakers (G933), Specialized Cleaners (G932), } \\
\text { Residential Cleaning and Support Workers (G931). }\end{array}$ & D \\
\hline \multirow[t]{3}{*}{$\begin{array}{l}\text { Trades, Transport and Equipment } \\
\text { Operators and Related } \\
\text { Occupations }(\mathrm{H})\end{array}$} & $\begin{array}{l}\text { *Carpenters (H121), Steamfitter and Pipefitters (H112), } \\
\text { Roofers (H141), Heavy-Duty Equipment Mechanics } \\
\text { (H412), Machinists (H311), Industrial Electricians (H212), } \\
\text { Ironworkers (H324), Welders (H326), *Crane operators } \\
\text { (H621). }\end{array}$ & B \\
\hline & Courier Drivers (H714). & C \\
\hline & Construction Labourers (H821), Surveyor Helpers (H822). & $\mathrm{D}$ \\
\hline $\begin{array}{l}\text { Unique to Processing, Manufacturing, } \\
\text { Utilities }(\mathrm{J})\end{array}$ & Labourers in Processing, Manufacturing and Utilities (J31). & D \\
\hline
\end{tabular}

Note. * Occupations first listed in September 24, 2007.

Sources: CNC (2007b, 2008), Statistics Canada (2006), HRSDC (2006).

\section{Appendix 2.}

\section{Variable definitions.}

urate $_{i, t}^{j}$ : Unemployment rate for occupation $i$ in province $j$ during year $t$. The data is for major groups based on NOC-S 2006 from 2002 to 2010 (Statistics Canada, 2013a, Table 2820010). 


\section{Macrothink}

Case Studies in Business and Management

ISSN 2333-3324

2017, Vol. 4, No. 1

Some annual unemployment rates were missing and linear extrapolated values were computed.

$D^{l}$ : Experiment region. The variable is equal to 1 for Alberta and British Columbia and 0 otherwise.

$D_{t}$ : Experiment period. The variable is equal to 0.25 for 2007; 1 for 2008 and 2009; 0.25 for 2010; and 0 otherwise.

$D_{m}$ : Treatment group. The variable is equal to 1 for occupation groups including E-LMO listed occupations and 0 otherwise.

EIqual: Minimum number of weeks of insurable employment necessary to qualify for benefits in each province (Schmitt \& Gross, 2012).

Unionrate: Provincial union coverage (Statistics Canada 2013a, Table 2820078).

Minwage: Real provincial minimum wages, nominal divided by Canadian CPI excluding changes in indirect taxes (Government of Canada, 2015; Statistics Canada, 2013a, v41755375).

Table A.2.1. Statistical characteristics of $\left(\right.$ urate $_{i, t}^{j}-$ urate $\left._{i, t-1}^{j}\right):$ 2003-2010

\begin{tabular}{|l|l|l|l|l|l|}
\hline & & \multicolumn{3}{|l|}{ Treatment occupation groups } & \multicolumn{2}{l|}{ Control occupation groups } \\
\hline & All & $\begin{array}{l}\text { Experiment } \\
\text { region }\end{array}$ & $\begin{array}{l}\text { Non-experiment } \\
\text { region }\end{array}$ & $\begin{array}{l}\text { Experiment } \\
\text { region }\end{array}$ & $\begin{array}{l}\text { Non-experiment } \\
\text { region }\end{array}$ \\
\hline Mean & -0.028 & -0.016 & -0.048 & -0.022 & -0.008 \\
\hline Max. & 12.80 & 9.00 & 12.80 & 5.00 & 10.20 \\
\hline Min. & -9.80 & -6.90 & -9.80 & -2.20 & -6.50 \\
\hline SD & 1.95 & 2.12 & 2.37 & 1.10 & 1.41 \\
\hline N & 1488 & 160 & 656 & 136 & 536 \\
\hline
\end{tabular}

\section{Copyright Disclaimer}

Copyright for this article is retained by the author(s), with first publication rights granted to the journal.

This is an open-access article distributed under the terms and conditions of the Creative Commons Attribution license (http://creativecommons.org/licenses/by/3.0/). 